\title{
Effects of Hatha Yoga Exercise on Serum Leptin and Metabolic Syndrome Factors in Menopause Obese Middle-Aged Women
}

Jeong-Ah Lee and Do-Yeon Kim*

Department of Physical Education, Kyung-Sung University, Busan 314-79, Korea

${ }^{1}$ Department of Physical Education, Pusan national University, Busan 109-735, Korea

Received April 12, 2010 /Accepted May 13, 2010

\begin{abstract}
The purpose of this study was to analyze the effects of Hatha Yoga exercise on serum leptin and metabolic syndrome factors in obese and menopausal middle-aged women. The subjects were 26 obese women divided into the Hatha Yoga exercise group $(n=13)$, which trained for 16 weeks, and the Control group $(n=13)$. Variables of body composition, serum leptin and metabolic syndrome factors were measured in all the subjects before and after the 16-week Hatha Yoga training. The results of the study in the Hatha Yoga group were as follows: body weight, \% fat, BMI, WC, WHR and VFA had significantly decreased, but SMM had increased. HDL-C had significantly increased, but leptin, TC, TG, LDL-C, insulin, glucose and HOMA-IR had decreased. The main variables affecting changes in VFA were \% body fat, BMI, WHR, TC, LDL-C, glucose, and HOMA-IR. Therefore, regular and continuous Hatha Yoga exercise was effective in improving body composition, visceral fat and serum lipids. Consequently, Hatha Yoga exercise will be effective in preventing cardiovascular disease caused by obesity in obesew and menopausal middle-age women.
\end{abstract}

Key words : Hatha Yoga, leptin, TG, HDL-C, WC, metabolic syndrome

\section{서 론}

지방조직이 과거에는 단순히 잉여 에너지인 중성지방 (triglyceride)을 저장하는 장소로 간주되어 왔으나, 최근에 렙 틴(leptin), 아디포넥틴(adiponectin), TNF-a (tumor necrosis factor-a) 등 다양한 아디포사이토카인(adipocytokine)이 분비 되는 것이 밝혀짐에 따라 지방조직은 단순한 에너지 저장 창 고가 아니라 생물학적으로 활발한 기능을 가진 내분비 기관이 라고 보고되고 있다[18,22].

특히 비만유전자에서 생산되는 렙틴은 지방조직의 양과 비 례하므로 비만자의 혈청 렙틴의 농도가 정상 체중자에 비하여 높게 나타나고, 내장지방보다는 피하지방에서 더 많이 생산되 는데[2,15], 이러한 렙틴은 지방세포의 내분비 개념으로 비만 연구에 중요한 역할을 하고, 섭식조절 뿐만 아니라 에너지 소 비와 생식기능까지 광범위하게 작용하며, 식욕을 억제하고 교 감신경계를 통하여 열생성을 증가시키고[16], 뇌를 순환하면 서 시상하부의 수용체에 작용하여 식이를 억제하는 것으로, 체내지방이 증가하면 뇌에서 분비되는 물질로서 뇌에 포만감 을 관장하는 만복중추(satiety center)를 자극해 식욕을 저해하 는 물질 중 하나로 밝혀졌다[21]. 또한 렙틴이 활발히 활동하면 식욕이 줄어드는 동시에 교감신경을 자극해 각각의 기관이 에너지를 소비하는 활동을 시작하게 된다[8].

*Corresponding author

Tel : +82-51-663-4956, Fax : +82-51-663-4959

E-mail : kdy4955@hotmail.com
체질량지수가 $35 \mathrm{~kg} \cdot \mathrm{m}^{-2}$ 이상인 비만자를 대상으로 3주간

의 유산소성운동과 저항성운동을 복합적으로 실시한 결과 혈 청 렙틴이 감소하였다고 보고하였다[23].

2001년 발표된 Third report of National Cholesterol Education Program (NCEP)의 Adult Treatment Panel (ATP) III에서는 대사증후군의 발생 위험인자로서 동맥경화성 지질 대사이상으로 중성지방과 저밀도지단백 콜레스테롤의 증가 및 고밀도지단백콜레스테롤의 감소를 포함한다[14].

특히 고밀도지단백 콜레스테롤의 증가는 관상동맥 질환을 감소시키는 효과를 가지고 있으며, 고밀도지단백 콜레스테롤 이 $10 \mathrm{mg} / \mathrm{dl}$ 변할 때 심혈관 질환의 위험도는 $50 \%$ 가 변하며 [5], 총 콜레스테롤이 증가하면 다른 위험요소가 없는 상태에 서도 심혈관 질환에 큰 영향을 미칠 수 있고, 저밀도지단백 콜레스테롤은 총 콜레스테롤의 $75 \%$ 이상을 차지하는데 관상 동맥질환을 발생시키는 위험인자로서 중요하다[10].

유산소운동이 혈청 중 총 콜레스테롤과 중성지방을 감소시 키고, 고밀도지단백 콜레스테롤을 증가시켜 심혈관계질환의 예방에 중요한 역할을 하고[25], 유산소성 운동을 주 3 6 회의 빈도로 매회 30 분 이상 3 개월 동안 지속하면 총콜레스테롤이 낮아지고 고밀도지단백 콜레스테롤이 증가하므로 관상동맥 질환을 예방할 수 있으며[20], 고밀도지단백 콜레스테롤이 35 $\mathrm{mg} / \mathrm{dl}$ 이하이면 심장질환의 발병 가능성이 높기 때문에 운동 을 통하여 고밀도지단백 콜레스테롤을 증가시켜야 한다[10]. 이와 같이 비만인에서 렙틴의 농도가 증가되어 있음이 보고 되고 있고, 비만으로 인한 대사증후군의 관련인자들이 복합적 
으로 연관되어 있음이 많은 연구들을 통해서 보고되고 있으나 운동으로 인한 렙틴의 농도변화와 대사증후군 관련인자들에 대한 논문이 미흡한 실정이다.

따라서 본 연구는 장기간의 규칙적인 하타요가 운동이 폐경 기 비만중년여성의 체중감량을 통한 체조성, 렙틴의 농도 및 대사증후군 관련인자들에 미치는 영향과 렙틴에 영향을 미치 는 대사증후군 관련인자들을 규명하기 위하여 실시하였다.

\section{재료 및 방법}

\section{연구대상}

본 연구는 B광역시에 거주하는 체지방률이 $35 \%$ 이상인 폐 경기 비만중년여성을 대상으로 본 연구의 목적 및 절차에 대 하여 충분히 이해하고 과거병력이 없고, 현재 특별한 질환이 없으며 평소 규칙적인 운동을 실시하지 않은 35 명의 피검자 중 본인의 희망에 따라 운동참가 희망자 19 명과 운동참가 불 가능한자 16 명을 선정하여 실시하였으나 운동기간 중 성실히 참가하지 않은 자와 측정 및 심사결과가 신뢰성이 없는 자를 제외한 후 하타요가집단 13 명과 통제집단 13 명, 총 26 명을 대 상으로 분석하였으며, 대상자의 신체적 특성은 Table 1 과 같다.

\section{측정 항목 및 방법}

\section{체조성 검사}

혈압은 10 분간 안정을 취한 후 수은혈압계(Hico, Japan)로 측정하였으며, 신장, 체중, 체지방률, 골격근량, 체질량지수,
허리둘레, 허리엉덩이둘레비 및 내장지방면적은 체성분분석 기(InBody 720)를 이용하여 측정하였다. 허리둘레(waist circumference)는 줄자를 이용하여 바닥과 수평을 이루고 배꼽부 위를 평행으로 지나도록 하고, 직립 자세에서 호기 말에 측정 하였고, 엉덩이 둘레는 옆에서 봤을 때 가장 볼록한 부위를 측정하여 2회 이상 측정하여 평균값을 기록하였다. WHR은 허리둘레를 엉덩이 둘레로 나눈 값으로 하였다.

\section{혈액 검사}

혈액검사는 운동 전과 16 주 후 12 시간 이상 공복상태를 유 지하여 전완 주정맥에서 1 회용 주사기(Bom Medrea Co, LTD) 를 사용하여 $15 \mathrm{ml}$ 를 채혈하여 글루코스(Glucose)는 효소법, 중성지방은 유리 Glycerol 소거법(TBA-200 FRNEO, Japan), 고밀도지단백 콜레스테롤과 저밀도지단백 콜레스테롤은 직 접측정법(TBA 200-FRNEO, Japan)으로, 렙틴은 RIA법(8 -Counter Cobra 5010, USA)으로 분석하였다. 인슐린 저항성 지수(HOMA -IR)는 다음의 공식에 의하여 산출하였다.

HOMA-IR $=$ fasting insulin $(\mu \mathrm{U} / \mathrm{ml}) \times$ fasting glucose $(\mathrm{mmol} / \mathrm{l}) / 22.5[19]$

\section{하타요가운동 프로그램}

Iyenger [9] 요가 프로그램을 참조로 체위(asana)를 수정보 완하여 구성하였고, 운동강도는 각 운동 동작마다 개인의 최 대운동범위(ROM)의 80 90\% 범위에서 실시하도록 하였으며, 주 3 회씩 매회 60 분간, 16 주간 실시하였으며, 하타요가운동 프로그램은 Table 2와 같다.

Table 1. Descriptive characteristics of the study participants

\begin{tabular}{ccccc}
\hline & Age $(\mathrm{yr})$ & Height $(\mathrm{cm})$ & Weight $(\mathrm{kg})$ & Body fat $(\%)$ \\
\hline Hatha Yoga $(\mathrm{n}=13)$ & $57.38 \pm 2.90$ & $157.13 \pm 4.64$ & $68.00 \pm 8.90$ & $38.08 \pm 3.53$ \\
Control $(\mathrm{n}=13)$ & $56.85 \pm 2.61$ & $156.69 \pm 4.06$ & $66.72 \pm 2.97$ & $36.53 \pm 2.72$ \\
\hline
\end{tabular}

Values are means \pm SD.

Table 2. Hatha Yoga exercise program

\begin{tabular}{|c|c|c|c|c|}
\hline Week & & Exercise & Intensity $(\%)$ & Duration $(\mathrm{sec})$ \\
\hline \multirow{5}{*}{$1 \sim 16$} & $\begin{array}{l}\text { Warm-up } \\
(10 \mathrm{~min})\end{array}$ & Neck rolls, Shoulder circles, Ankle circles, Stretching exercises & & \\
\hline & \multirow{3}{*}{$\begin{array}{l}\text { Main } \\
\text { exercise } \\
(40 \mathrm{~min})\end{array}$} & $\begin{array}{l}\text { 1. Sitting Asanas } \\
\text { Vajur, Danda, Janu Sirsa, Paschimottan, Bhadr, Parivrtta Janu Sirsa, } \\
\text { Biparita, Upavistha Kona, Purvottan, Gomukha, Marichya I }\end{array}$ & $80 \sim 90$ & $\begin{array}{c}7 \sim 8 \mathrm{sec} \\
2 \text { sets }\end{array}$ \\
\hline & & $\begin{array}{l}\text { 2. Standing Asanas } \\
\text { Tada, Urdhva Namaskar, Hastapada, Eka Pada Prasarana, Bhudra, } \\
\text { Bhujanga I , Bhujanga II, Adhomukha Svana, Eka Pada Prasarana, } \\
\text { Hastapada, Urdhva Namaskara, Namaskara }\end{array}$ & $80 \sim 90$ & $\begin{array}{l}7 \sim 8 \mathrm{sec} \\
2 \text { cycles }\end{array}$ \\
\hline & & $\begin{array}{l}\text { 3. Back Bends \& Reclining Asanas } \\
\text { Vidala, Shashaunga, Urdhva Dhanura, Dhanura, Matsya, Supta } \\
\text { Padangustha, Jathara Parivartana, Hala, }\end{array}$ & $80 \sim 90$ & $\begin{array}{c}7 \sim 8 \mathrm{sec} \\
2 \text { sets }\end{array}$ \\
\hline & $\begin{array}{l}\text { Cool-down } \\
(10 \mathrm{~min})\end{array}$ & Savasana, Lying leg swinging, Relaxation, Nadishodhna & & \\
\hline
\end{tabular}




\section{자료 처리}

SPSS/PC Version 14.0 프로그램을 이용하여 집단별, 요인 별 평균과 표준편차를 산출하고, 운동 프로그램의 실시 전과 12 주 후의 차이검정은 paired $t$-test, 하타요가집단과 통제집단 의 차이검정은 $t$-test로 하였으며, 렙틴에 영향을 미치는 요인 을 규명하기 위하여 대사증후군인자 요인에 대하여 후진법 (backward selection)에 의한 선형회귀분석(Line Dancear regression analysis)을 실시하였고, 통계적 유의수준은 $a=0.05$ 로 하였다.

\section{결 과}

\section{체조성과 내장지방면적의 변화}

운동전과 16 주간 하타요가운동 후 체조성과 내장지방면적 의 변화는 Table 3 과 같다.

집단내에서 하타요가집단은 체중(weight), 체지방률 $(\% \mathrm{BF})$, 체질량지수(BMI), 허리둘레(WC), 허리엉덩이둘레비(WHR) 및 내장지방면적(VFA)은 유의하게 감소하였고 $(\mathrm{p}<0.01)$, 골격 근량 $(\mathrm{SMM})$ 은 유의하게 증가하였으나 $(\mathrm{p}<0.01)$, 통제집단은 체 중, 체지방률, 체질량지수, 허리둘레 및 내장지방면적은 유의 하게 증가하였고 $(\mathrm{p}<0.01)$, 골격근량은 유의하게 감소하였다 $(\mathrm{p}<0.01)$. 집단간의 차이는 운동실시 전에는 모든 요인에서 유 의한 차이가 나타나지 않았으나, 후에는 체중, 체질량지수, 허 리둘레 및 허리엉덩이둘레비는 유의한 차이가 나타나지 않았
으나, 체지방률 및 내장지방면적은 하타요가집단이 통제집단 보다 유의하게 낮게 나타났고 $(\mathrm{p}<0.01)$, 골격근량은 유의하게 높게 나타났다 $(\mathrm{p}<0.01)$.

\section{렙틴과 대사증후군 인자의 변화}

운동전과 16 주간 하타요가운동 후 렙틴과 대사증후군 인자 의 변화는 Table 4 와 같다.

집단내에서 하타요가집단은 렙틴, 총콜레스테롤(TC), 중성 지방(TG), 저밀도지단백 콜레스테롤(LDL-C), 수축기혈압 (SBP), 이완기혈압(DBP) 및 글루코스는 유의하게 감소하였으 나 $(\mathrm{p}<0.01)$, 고밀도지단백콜레스테롤(HDL-C), 인슐린 및 인 슐린저항성지수는 유의한 차이가 나타나지 않았다. 통제집단 은 HDL-C는 유의하게 감소하였고 $(\mathrm{p}<0.01)$, 렙틴, $\mathrm{TC}, \mathrm{TG}$, $\mathrm{LDL}-\mathrm{C}, \mathrm{SBP}, \mathrm{DBP}$, 인슐린, 글루코스 및 인슐린저항성지수는 유의하게 증가하였다 $(\mathrm{p}<0.01)$.

집단간의 차이는 운동실시 전에는 모든 요인에서 유의한 차이가 나타나지 않았으나, 후에는 HDL-C는 하타요가집단이 통제집단보다 유의하게 높게 나타났으나 $(\mathrm{p}<0.01)$, 렙틴, $\mathrm{TC}$, TG, LDL-C, SBP, DBP, 인슐린 및 인슐린저항성지수는 하타요 가집단이 통제집단보다 유의하게 낮게 나타났고 $(\mathrm{p}<0.05)$, 글 루코스는 유의한 차이가 나타나지 않았다.

렙틴과 대시증후군인자의 회귀분석

16 주간 하타요가운동 후 렙틴과 대사증후군인자의 회귀분

Table 3. Changes in body composition and VFA after 16 weeks Hatha Yoga exercise

\begin{tabular}{|c|c|c|c|c|}
\hline Variable & Group & Pre-test & Post-test & paired $t$ \\
\hline \multirow{3}{*}{$\begin{array}{c}\text { Weight } \\
(\mathrm{kg})\end{array}$} & Hatha Yoga & $68.00 \pm 8.90$ & $65.92 \pm 8.30$ & $4.128^{* * *}$ \\
\hline & Control & $66.72 \pm 2.97$ & $68.49 \pm 2.93$ & $-9.556^{* * *}$ \\
\hline & $t$-value & 0.491 & -1.051 & \\
\hline \multirow{3}{*}{$\begin{array}{c}\text { Body fat } \\
(\%)\end{array}$} & Hatha Yoga & $38.08 \pm 3.53$ & $35.88 \pm 3.42$ & $5.393^{* * *}$ \\
\hline & Control & $36.53 \pm 2.72$ & $38.79 \pm 2.66$ & $-7.483^{* * *}$ \\
\hline & $t$-value & 1.251 & $-2.425^{*}$ & \\
\hline \multirow{3}{*}{$\begin{array}{c}\text { SMM } \\
(\mathrm{kg})\end{array}$} & Hatha Yoga & $22.15 \pm 2.08$ & $25.24 \pm 2.23$ & $-5.428^{* * *}$ \\
\hline & Control & $23.35 \pm 1.63$ & $21.95 \pm 1.70$ & $6.343^{* * *}$ \\
\hline & $t$-value & -1.636 & $4.216^{* * *}$ & \\
\hline \multirow{3}{*}{$\begin{array}{c}\text { BMI } \\
\left(\mathrm{kg} \cdot \mathrm{m}^{-2}\right)\end{array}$} & Hatha Yoga & $27.50 \pm 3.02$ & $26.61 \pm 3.01$ & $4.263^{* * *}$ \\
\hline & Control & $27.28 \pm 1.48$ & $27.97 \pm 1.33$ & $-7.668^{* * *}$ \\
\hline & $t$-value & 0.239 & -1.493 & \\
\hline \multirow{3}{*}{$\begin{array}{l}\text { WC } \\
(\mathrm{cm})\end{array}$} & Hatha Yoga & $97.41 \pm 7.01$ & $92.04 \pm 5.39$ & $4.477^{* * *}$ \\
\hline & Control & $93.10 \pm 4.53$ & $95.71 \pm 5.55$ & $-4.701^{* * *}$ \\
\hline & $t$-value & 1.861 & -1.708 & \\
\hline \multirow{3}{*}{ WHR } & Hatha Yoga & $0.94 \pm .035$ & $0.93 \pm .032$ & $4.466^{* * *}$ \\
\hline & Control & $0.93 \pm .017$ & $0.94 \pm .018$ & $-5.112^{* * *}$ \\
\hline & $\mathrm{t}$-value & 2.045 & -0.741 & \\
\hline \multirow{3}{*}{$\begin{array}{l}\text { VFA } \\
\left(\mathrm{cm}^{2}\right)\end{array}$} & Hatha Yoga & $124.25 \pm 14.44$ & $113.76 \pm 13.66$ & $6.645^{\star * *}$ \\
\hline & Control & $116.65 \pm 7.35$ & $123.50 \pm 6.35$ & $-9.075^{* * *}$ \\
\hline & $t$-value & 1.693 & $-2.330^{*}$ & \\
\hline
\end{tabular}

${ }^{*} p<0.05, * * * \quad p<0.001$

SMM: skeletal muscle mass, BMI: body mass index, WC: waist circumference, WHR: waist-to-hip ratio, VFA: visceral fat area 
Table 4. Changes in leptin and metabolic syndrome factors

\begin{tabular}{|c|c|c|c|c|}
\hline Variable & Group & Pre-test & Post-test & paired $t$ \\
\hline \multirow{3}{*}{$\begin{array}{l}\text { Leptin } \\
(\mu \mathrm{g} / \mathrm{ml})\end{array}$} & Hatha Yoga & $12.09 \pm 4.49$ & $7.88 \pm 2.74$ & $4.223^{* * *}$ \\
\hline & Control & $9.96 \pm 3.46$ & $11.43 \pm 2.91$ & $-3.127^{* * *}$ \\
\hline & $t$-value & 1.352 & $-3.198^{* *}$ & \\
\hline \multirow{3}{*}{$\begin{array}{c}\mathrm{TC} \\
(\mathrm{mg} / \mathrm{dl})\end{array}$} & Hatha Yoga & $193.85 \pm 21.19$ & $184.54 \pm 16.92$ & $4.475^{* * *}$ \\
\hline & Control & $180.38 \pm 17.10$ & $199.54 \pm 16.63$ & $-5.757^{* * *}$ \\
\hline & $t$-value & 1.782 & $-2.280^{*}$ & \\
\hline \multirow{3}{*}{$\begin{array}{c}\mathrm{TG} \\
(\mathrm{mg} / \mathrm{dl})\end{array}$} & Hatha Yoga & $106.92 \pm 42.61$ & $73.31 \pm 30.96$ & $4.062^{* *}$ \\
\hline & Control & $82.69 \pm 22.55$ & $111.53 \pm 23.30$ & $-6.242^{* * *}$ \\
\hline & $t$-value & 1.812 & $-3.557^{* *}$ & \\
\hline \multirow{3}{*}{$\begin{array}{l}\text { HDL-C } \\
(\mathrm{mg} / \mathrm{dl})\end{array}$} & Hatha Yoga & $57.36 \pm 12.59$ & $62.01 \pm 12.17$ & -1.793 \\
\hline & Control & $56.21 \pm 6.73$ & $50.02 \pm 6.57$ & $4.983^{* * *}$ \\
\hline & $t$-value & 0.291 & $3.125^{* *}$ & \\
\hline \multirow{3}{*}{$\begin{array}{l}\text { LDL-C } \\
(\mathrm{mg} / \mathrm{dl})\end{array}$} & Hatha Yoga & $125.38 \pm 21.43$ & $112.00 \pm 18.75$ & $5.294^{* * *}$ \\
\hline & Control & $115.62 \pm 16.15$ & $131.92 \pm 17.11$ & $-3.236^{* *}$ \\
\hline & $t$-value & 1.313 & $-2.830^{* *}$ & \\
\hline \multirow{3}{*}{$\begin{array}{c}\text { SBP } \\
(\mathrm{mmHg})\end{array}$} & Hatha Yoga & $128.00 \pm 5.43$ & $122.08 \pm 4.41$ & $3.054^{* *}$ \\
\hline & Control & $124.69 \pm 6.21$ & $128.23 \pm 2.83$ & $-2.164^{*}$ \\
\hline & $t$-value & 1.446 & $-4.236^{* * *}$ & \\
\hline \multirow{3}{*}{$\begin{array}{c}\text { DBP } \\
(\mathrm{mmHg})\end{array}$} & Hatha Yoga & $85.00 \pm 4.16$ & $78.54 \pm 3.82$ & 4.650 *** \\
\hline & Control & $82.07 \pm 2.75$ & $86.38 \pm 3.33$ & $-3.683^{* *}$ \\
\hline & $t$-value & 2.112 & $-5.581^{* * *}$ & \\
\hline \multirow{3}{*}{$\begin{array}{l}\text { Insulin } \\
(\mu \mathrm{U} / \mathrm{ml})\end{array}$} & Hatha Yoga & $10.02 \pm 3.44$ & $8.56 \pm 6.61$ & 0.989 \\
\hline & Control & $9.67 \pm 4.24$ & $13.69 \pm 3.25$ & $-2.429^{*}$ \\
\hline & $t$-value & 0.229 & $-2.513^{*}$ & \\
\hline \multirow{3}{*}{$\begin{array}{l}\text { Glucose } \\
(\mathrm{mmol} / \mathrm{l})\end{array}$} & Hatha Yoga & $5.91 \pm 1.26$ & $5.32 \pm .75$ & $2.592^{*}$ \\
\hline & Control & $5.25 \pm 0.75$ & $5.74 \pm .72$ & $-5.501^{* * *}$ \\
\hline & $t$-value & 1.620 & -1.438 & \\
\hline \multirow{3}{*}{ HOMA-IR } & Hatha Yoga & $2.59 \pm 0.86$ & $2.03 \pm 1.52$ & 1.587 \\
\hline & Control & $2.29 \pm 1.05$ & $3.48 \pm .91$ & $-3.127^{* *}$ \\
\hline & $t$-value & 0.771 & $-2.947^{* *}$ & \\
\hline
\end{tabular}

* $p<0.05,{ }^{* *} p<0.01,{ }^{* * *} p<0.001$

TC: total cholesterol, TG: triglyceride, HDL-C: high-density lipoprotein cholesterol, LDL-C: low-density lipoprotein cholesterol, SBP: systolic blood pressure, DBP: diastolic blood pressure, HOMA-IR: homeostasis model assessment insulin resistance index

\section{석결과는 Table 5 와 같다.}

하타요가집단의 렙틴에 영향을 미치는 대사증후군인자의 요인으로는 HDL-C로 나타났으며, 독립변인의 통계적 유의성 을 판단하기 위한 $t$ 값은 HDL-C로 나타났고 $(\mathrm{p}<0.05)$, 베타계 수는 -0.684 로 나타났다.

\section{고 찰}

활동적인 여성들은 좌업생활을 하는 여성들보다 총 콜레스 테롤(TC), 중성지방 $(\mathrm{TG})$, 저밀도지단백 콜레스테롤농도가 낮
으며, 고밀도지단백 콜레스테롤의 수준이 높아 관상심장질환 의 위험률이 낮지만, 좌업생활을 하는 여성의 경우는 관상심 장질환의 발병률이 매년 증가하는 추세를 보인다고 하였다[7]. 이러한 여성비만은 영양과다 섭취보다는 신체활동과 활동 폭의 위축이 더 큰 원인으로 중년여성의 중성지방농도는 관상 질환의 예견인자이며, 당뇨, 비만증, 낮은 고밀도지단백 콜레 스테롤농도와 높은 중성지방농도가 관상심질환에 복합적으 로 관여하는데[6], 일반적으로 규칙적인 유산소 운동은 체조 성, 콜레스테롤, 고혈압과 혈당 수준 및 비만 등의 위험 요인을 개선시키고, 심혈관 기능을 향상시켜 관상동맥 질환 등의 심

Table 5. Regression analysis of leptin and metabolic syndrome factors in Hatha Yoga exercise

\begin{tabular}{ccccccc}
\hline Independent variables & $B$ & $S E B$ & Beta & $t$-value & $F$ & $\mathrm{R}^{2}$ \\
\hline Constant & -1.292 & 17.711 & & -0.073 & \multirow{2}{*}{$4.208^{*}$} & $676^{*}$ \\
HDL-C & -0.154 & 0.054 & -0.684 & $-2.868^{*}$ & \\
\hline
\end{tabular}

\footnotetext{
${ }^{*} p<0.05$ HDL-C: High-density lipoprotein cholesterol
} 
혈관계 질환을 예방하거나 그 진행을 억제 및 지연시킨다[4]. 비만중년여성을 대상으로 16 주간 하타요가 운동을 실시한 결과 체중, 체지방률, 체질량지수, 허리둘레, 허리엉덩이둘레 비 및 내장지방면적이 유의하게 감소하였으며, 제지방량은 유 의하게 증가하였고[12], 40대 중년여성을 대상으로 3년 이상의 규칙적인 운동을 하고 있는 헬스집단과 수영집단 및 규칙적인 운동을 하지 않은 통제집단과 비교한 결과 헬스집단과 수영집 단이 통제집단보다 총 콜레스테롤과 저밀도지단백 콜레스테 롤은 유의하게 낮았고, 고밀도지단백 콜레스테롤은 유의하게 높았으며[11], 20 50대 성인남녀 116명을 대상으로 체질량지 수가 $25 \mathrm{~kg} \cdot \mathrm{m}^{2}{ }^{2}$ 미만의 대조군과 이상의 비만군으로 구분하 여 연구한 결과 비만군에서 총 콜레스테롤, 중성지방 및 저밀 도지단백 콜레스테롤은 유의하게 높았고, 고밀도지단백 콜레 스테롤은 유의하게 낮았다고 보고하였다[26].

지질대사 작용은 여성이 생식능력기간 동안 항동맥경화인 자인 고밀도지단백 콜레스테롤(HDL-C)의 수치는 남성보다 높고, 저밀도지단백 콜레스테롤(LDL-C)의 수치는 낮게 나타 나지만 폐경기 이후에는 성에 따른 차이가 거의 보이지 않는 다[13]. 이러한 결과는 폐경기 이후 난포호르몬 결핍에 의한 난소기능의 저하로 에스트로젠 자극 저밀도지단백 수용체 활 동의 감소가 이루어져 저밀도지단백 콜레스테롤의 수준은 증 가하나, 고밀도지단백 콜레스테롤의 수준은 감소함으로써 갱 년기 여성들의 관상심장질환의 위험률이 증가하게 된다[7]. 성인남여 7,000명을 대상으로 낮은 고밀도 지단백 콜레스테 롤혈증과 관련된 인자를 연구한 결과 비만, 흡연, 고중성지방 혈증이 위험인자로 나타났으며, 낮은 고밀도지단백 콜레스테 롤혈증을 예방하기 위해서는 체중조절개선이 중요하다고 하 였다[24].

정상인의 경우 지방세포가 많아지면 렙틴분비도 항진되어 식욕이 감소되고 지방세포가 줄어들면 렙틴분비량이 감소하 여 식욕을 증가시키지만 비만환자인 경우 이러한 조절기전의 장애가 발생하여 혈중 렙틴수치가 높아도 식욕을 억제할 수 없는 것으로 알려지고 있다[17].

렙틴은 에너지대사의 신체항상성을 유지하기 위한 중추신 경계의 조절과정에서 인슐린보다 더욱 중요한 역할을 담당하 는 것으로 렙틴결핍은 비만을 유도하지만, 오히려 비만인에서 혈중 렙틴농도는 증가된 경향을 나타내고 있는데 이는 렙틴저 항성으로 비만 발생과정에서 대뇌에 대한 렙틴 작용의 감소에 기인한다[3].

주 3 회, 3 년 이상 실시하고 있는 40 대 중년여성의 댄스스포 츠 집단과 요가운동집단, 운동을 전혀 실시하지 않은 40 대 중 년여성인 일반집단을 대상으로 비교 연구한 결과 렙틴은 세 집단간 유의한 차이가 나타나지 않았다고 하였다[1].

본 연구에서 하타요가 운동을 실시한 후 렙틴은 $37.94 \%$ 가 유의하게 감소하였으며, 통제집단은 렙틴이 $13.89 \%$ 가 증가한 것으로 나타났다. 집단간의 차이는 운동실시 전에는 두 요인
모두 유의한 차이가 나타나지 않았으며, 운동실시 후에는 운 동집단이 통제집단보다 렙틴은 유의하게 낮게 나타났다 $(\mathrm{p}<0.05)$. 이러한 결과는 많은 선행연구의 결과와 일치하거나 유사한 것으로 나타나, 장기간의 규칙적인 하타요가운동이 체 중감량을 통해 성장호르몬의 분비를 자극시켜 지방분해를 촉 진시키고 따라서 렙틴의 감소로 균형을 이루며 이에 에너지대 사 조절에 따른 인슐린 저항을 감소시켜 대사질환 및 심혈관 질환의 예방에 긍정적인 효과가 있었던 것으로 사료된다.

본 연구에서 폐경기 비만중년여성을 대상으로 16 주간 하타 요가 운동을 실시한 결과 체조성과 내장지방면적의 변화에서 체중과 체지방률, 체질량지수, 허리둘레, 허리엉덩이둘레비 및 내장지방면적이 유의하게 감소하였으며, 골격근량은 유의 하게 증가하였고, 렙틴과 대사증후군 인자의 변화에서 고밀도 지단백 콜레스테롤은 유의하게 증가하였고, 총 콜레스테롤, 중성지방, 저밀도지단백 콜레스테롤, 수축기혈압, 이완기혈 압, 인슐린, 글루코스 및 인슐린 저항성지수는 유의하게 감소 된 것으로 나타나 체중감량으로 인한 렙틴저항성이 개선됨에 따라 렙틴의 농도가 유의하게 감소되었다는 선행연구들의 결 과들과 일치하는 것으로 나타났으며, 렙틴에 영향을 미치는 대사증후군인자는 고밀도지단백 콜레스테롤로 나타나, Grundy [7]의 폐경기 이후 난포호르몬 결핍에 의한 난소기능 의 저하로 고밀도지단백 콜레스테롤의 수준이 감소함으로써 갱년기 여성들의 관상심장질환의 위험률이 증가하게 된다는 보고와 서문성 등[24]이 비만은 낮은 고밀도 지단백 콜레스테 롤혈증의 위험인자로, 낮은 고밀도지단백 콜레스테롤혈증을 예방하기 위해서는 체중조절개선이 중요하다고 보고한 결과 와 일치하는 것으로 나타났다.

본 연구에서 폐경기 비만여성을 대상으로 하타요가 운동을 16 주간 실시하여 운동의 효과를 분석한 결과 다음과 같은 결 론을 얻었다.

첫째, 하타요가집단의 체중, 체지방률, 체질량지수, 허리둘 레, 허리엉덩이둘레비 및 내장지방면적은 유의하게 감소하였 으나, 골격근량은 증가하였다.

둘째, 통제집단에 비교하여 하타요가집단이 고밀도지단백 콜레스테롤은 유의하게 증가하였으나, 총 콜레스테롤, 중성지 방, 저밀도지단백 콜레스테롤, 수축기혈압, 이완기혈압, 인슐 린, 글루코스 및 인슐린 저항성지수는 감소하였다.

셋째, 하타요가집단의 렙틴에 영향을 미치는 대사증후군 인 자의 회귀분석결과에서는 고밀도지단백 콜레스테롤로 나타 났다.

이상의 결과에서 폐경기 비만중년여성들의 에너지균형을 유지하기 위해서는 유산소운동인 하타요가운동을 규칙적으 로 실시하여 체중조절을 통한 고밀도지단백 콜레스테롤수준 을 향상시키고, 렙틴저항성을 개선함으로서 대사증후군 위험 요인을 개선시킬 수 있을 것으로 사료된다. 


\section{References}

1. Ahn, K. S. 2007. Effects of dance sport exercise on bone metabolic hormone, bone mineral density and serum lipids in middle-aged women. PhD. Dissertation, Kyungsung University, Busan, Korea.

2. Considine, R. V. 1997. Invited editoral on "Acute and chronic effects of exercise on leptin levels in humans". J. Appl. Physid. 83,34 .

3. Considine, R. V., E. L. Considine, C. J. Williams, T. M. Hyde, and J. F. Caro. 1996. The hypothalamic leptin receptor in humans: identification of incidental sequence polymorphism and absence of the $\mathrm{db} / \mathrm{db}$ mouse and $\mathrm{fa} / \mathrm{fa}$ rat mutations. Diabetes 45, 992-994.

4. Cooper, K. H. 1982. The aerobic program for total well-being. New York: M. Evans and Company, Inc.

5. Goldberg, L., D. L. Elliot, R. W. Schutz, and F. E. Kloster. 1984. Changes in lipid and lipoprotein levels after weight training. JAMA 252, 504-506.

6. Gordon, T., W. P. Castelli, M. C. Hjortland, W. B. Kannel, and T. R. Dawber. 1977. Diabetes, blood lipids, and the role of obesity in coronary heart disease risk for women. The Framingham Study. Ann. Intern. Med 87, 393-397.

7. Grundy, S. M. 1990. Cholesterol and coronary heart disease. Future directions. JAMA 264, 3053-3059.

8. Haynes, W. G. 2000. Interaction between leptin and sympathetic nervous system in hypertension. Curr. Hypertens Rep. 2, 311-318.

9. Iyengar, B. K. S. 2001. Yoga: The path to holistic health London: Dorling Kindersley.

10. Jones, P. H. and A. M. Gotto. 1990. Assessment of lipid abnormalities in the heart, pp. 378-384, In Hurst. J. W. (ed.), 7th eds. International Edition.

11. Kim, K. B., S. B. Kim, and J. A. Lee. 2004. Effects of resistive and aerobic exercise on body composition and blood lipids in middle-aged women. J. Korea Sport Res. 15, 1125-1134.

12. Kim, K. B. and J. A. Lee. 2007. Effects of hatha yoga exercise on serum adiponectin and metabolic syndrome factors in obese middle-aged women. The Korean J. Phys. Edu. 46, 389-397.

13. Kim, M. H. 1987. Women's internal disease Dan-kwang, Seoul, Korea.

14. Lepor, N. E. and R. E. Vogel. 2001. Summary of the third report of the National Cholesterol Education Program Adult Treatment Panel III. Rev. Cardiovasc. Med 2, 160-165.
15. Lonnqvist, F., L. Nordfors, M. Jansson, A. Thorne, M. Schalling, and P. Arner. 1997. Leptin secretion from adipose tissue in women. Relationship to plasma levels and gene expression. J. Clin. Invest. 99, 2398-2404.

16. Mantzoros, C. S. 1999. The role of leptin in human obesity and disease: A review of current evidence. Ann. Intern. Med 130, 671-680.

17. Matsubara, M.. S. Maruoka, and S. Karayose. 2002. Inverse relationship between plasma adiponectin and leptin concentrations in normal-weight and obese women. Eur. J. Endocrinol. 147, 173-180.

18. Matsuzawa, Y., T. Funahashi, and T. Nakamura. 1999. Molecular mechanism of metabolic syndrome $\mathrm{X}$ : contribution of adipocytokines adipocyte-derived bioactive substances. Ann. Ny. Acad Sci. 892, 146-154.

19. Matthews, D. R., J. P. Hosker, A. S. Rudenski, B. A. Naylor, D. F. Treacher, and R. C. Turner. 1985. Homeostasis model assessment: insulin resistance and beta-cell function from fasting plasma glucose and insulin concentrations in man. Diabetologia 28, 412-419.

20. Motoyama, M., Y. Sunami, F. Kinoshita, T. Irie, J. Sasaki, K. Arakawa, A. Kiyonaga, H. Tanaka, and M. Shindo. 1995. The effects of long-term low intensity aerobic training and detraining on serum lipid and lipoprotein concentrations in elderly men and women. Eur. J. Appl. Physid. Occup. Physiol. 70, 126-131.

21. Roemmich, J. N. and A. D. Rogol. 1999. Hormonal changes during puberty and their relationship to fat distribution. Am J. Hum Biol. 11, 209-224.

22. Saltiel, A. R. 2001. You are what you secrete. Nat. Med 7, 887-888.

23. Sartorio, A., F. Agosti, M. Resnik, and C. L. Lafortuna. 2003. Effects of a 3-week integrated body weight reduction program on leptin levels and body composition in severe obese subjects. J. Endcrinol. Invest. 26, 250-256.

24. Suh, M. S., H. G. Lee, Y. S. Yoon, W. S. Sun, and H. S. Park. 2001. Factors associated low HDL-cholesterol in adults. The Korean Academy of Family Medicine 22, 1214-1223.

25. Sun, Y. 1991. Study of exercise and serum lipids in puberty. Zhonghua Liu Xing Bing Xue Za Zhi 12, 193-196.

26. Yang, J. W., J. In. Park, S. Y. Kim, J. Ch. Kim, K. J. Kim, and D. Y. L. 2005. Plasma Ghrelin levels in obese adults: The relationship to obesity indices. The Korean J. Obes. 14, 47-54. 
초록 : 하타요가 운동이 폐경기 비만중년여성의 렙틴농도와 대사증후군 인자에 미치는 영향 이정아 · 김도연 ${ }^{1} \star$

(경성대학교 체육학과, ${ }^{1}$ 부산대학교 체육교육과)

본 연구는 체지방률이 $35 \%$ 이상인 폐경기 비만중년여성 26 명을 대상으로 하타요가 운동이 체조성과 렙틴 및 대사증후군관련인자에 미치는 영향과 렙틴에 영향을 미치는 대사증후군인자들을 규명하기 위하여 하타요가 운 동을 16 주간 실시한 후 운동전과 후의 체조성, 렙틴 및 대사증후군인자를 측정하여 비교분석하였다. 본 연구의 결과 운동 후에 하타요가집단에서 체중, 체지방률, 체질량지수, 허리둘레, 허리엉덩이둘레비 및 내장지방면적이 유의하게 감소하였고, 골격근량(SMM)은 증가하였다. 고밀도지단백 콜레스테롤(HDL-C)은 유의하게 증가하였고, 렙틴, 총콜레스테롤(TC), 중성지방(TG), 저밀도지단백 콜레스테롤(LDL-C), 인슐린, 글루코스 및 인슐린저항성지 수(HOMA-IR)는 유의하게 감소하였으며, 하타요가집단의 렙틴에 영향을 미치는 대사증후군인자는 HDL-C로 나 타났다. 이상과 같이 하타요가운동으로 체지방의 감량이 렙틴저항성을 개선하여 렙틴의 감소와 대사증후군인자 의 개선으로 생활습관병을 예방하는 데 효과가 있을 것으로 사료된다. 